\title{
The Responsibility of Human Resource Management and Development Professionals in the Development of Low-Skilled Workers in the Nigeria Public Sector
}

\author{
Stephen Talabi Aroge, $\mathrm{PhD}$ \\ Departments of Arts education, Faculty of Education, Adekunle Ajasin University \\ Akungba-Akoko, Ondo State, Nigeria \\ Tel: 234-703-230-3565 E-mail: draroge@yahoo.com \\ Moshood Ayinde Hassan, $\mathrm{PhD}$ \\ Departments of Arts education, Faculty of Education, Adekunle Ajasin University \\ Akungba-Akoko, Ondo State, Nigeria \\ Tel: 234-803-422-9218Ｅ-mail: ayindeayindeayinde@hotmail.com
}

Received: March 17, 2011

doi:10.5539/ijbm.v6n11p227
Accepted: July 13, $2011 \quad$ Published: November 1, 2011

URL: http://dx.doi.org/10.5539/ijbm.v6n11p227

\begin{abstract}
The need for making human asset of an economy, public and private, relevant and adequately responsive to the growth and development of the nation is stressed in this paper. Public sector is owned and controlled by the government. This makes government to be the largest employer of labour. The onus of developing human resources largely devolves on employers of labour. Human resources are relevant in organization for they make things happen. The paper critically examined the concept of human resource, human resource management and workers development and training as well as the relevance of human resource and the need for employee development in an organization. This paper submits that training and re-training of workers is needed, especially for low-skilled workers for any organization to survive and realize its goals in this era of globalization and competitive economy.
\end{abstract}

Keywords: Human resources management, Development professionals, Low-skilled workers, Responsibility of human resources management

\section{Introduction}

There has always been the growing concern and conviction on the need for making the human asset of an economy, private and public sector alike, to be highly relevant and adequately responsive in terms of their effective and efficient contributions towards an all-round growth and development of such economy. This is realizable through the adoption and use of human capital development concept and practice as a strategic means for bringing about the much desired overall well-being of the economy, and invariably the nation at large. This calls for transformation of all segments of the entire stock of the human resource in terms of knowledge, intelligence, experiences and expertise; all of which required are to be updated continually for currency and efficient productivity.

The centrality of the development of such human resource (the workers) of all types within an economy (be they skilled, semi-skilled, low skilled and unskilled) is not in anyway in contest. This is in view of the fact that the nature of the world economic realities has now made every nation's economy to become knowledge driven and thus has essentially imposed additional responsibilities on all the stakeholders, especially those charged with skill provision and skill development. Effort has been to update the level of competencies of workers, in terms of knowledge, skills, relevant information and aptitude, in the context of national economic development, by the in-house human resource development managers in the public sector and the outsourced professional skills providers as consultants.

In view of the importance of the human element, successive Nigerian government at all levels have put up varying efforts aimed at providing required competencies of the nation's entire workforce. Such efforts include those actions spelt out in the government human resource development policy, and complemented by the government agencies and government employees, government educational institutions and training institutions, private training organizations as well as individual human resource development consulting firms. The internal human resource development workers use the in-house human resource development units to ensure proper utilization of internal employee training, development facilities and programmes. The unit equally facilitates a collaborative agenda with external human resource organs towards the evolvement of a synergy that will fast-track the development of employees of all categories, especially the low-skilled workforce in the Nigerian public sector. 
The thrust of this paper is to examine the responsibilities of both the internal human resources development and outsourced professional development bodies in the development of low - skilled workers in the public sector, Nigeria. Therefore, effort is made to, among others:

(i) give a cursory look at what constitute public sector in the Nigerian context;

(ii) explain the terms of "human resource management" and its roles in employee development efforts;

(iii) examine the issue of professional human developers and their contributions to the development of low-skilled workers;

(iv) give a brief explanation of human resource development in the public sector of the Nigerian economy as compared to the private sector; and

(v) explore the processes and who should shoulder the responsibility of developing low-skilled workers in Nigeria as well as the discussion of the concept of human capital development.

\section{The Nigerian Public Sector}

The concept and structure of what is today known and operated as the Nigerian public service sector of the entire economy has been premised on the nation's public administration system based on its colonial experience. Thus, what constitutes the public service sector in Nigeria is one of the legacies bequeathed to the country at its independence. The sector has largely remained a semblance of what obtains in the context of colonial master's home politico-economic model of running public undertakings. The public service is that sector of the economy owned and controlled by the governments of the federation or their agencies. It is a sector which is expected to serve all the citizens and it is funded and administered from and by the public resources. Essentially, the Nigerian public service sector, according to Otobo and Omole (1981) and MAMSER (1987) is economically divided into three categorizations:

(1) The Civil service: This category can be identified as the federal, state, state ministries as well as the local government councils.

(2) The institutions of learning, research institute and other allied systems.

(3) The parastatals: These are Federal and State corporations like the Nigerian Railway Corporation, Housing Corporation, Port Authorities, Air and Sea, Crude oil and Solid mineral Ventures and Transportation undertakings. Others include the Power Holding Company of Nigeria, Water Corporation, Nigerian Television Authority (NTA), Federal and State Radio Corporations, The Nigerian Postal Service (NIPOST), Federal and State Waste Management Board; the Banking industry, among others.

These parastatals are supposed to provide certain essential services to members of the public even if they are unable to make profits or at least break even. The public enterprises are businesses set up to make profits and they must operate fully as commercial enterprises. Some of these enterprises are owned wholly by the governments and in other cases the governments have the majority or minority shares as the case may be. Presently, as opined by Otobo and Omole (1987), the Nigerian Public Service Sector, when compared to the private sector of the economy, constitutes various categories of employees requiring varying skills in level and content as regards their job holding. Thus, the employees in these categories form the largest number of those employed in the country. As would be expected, they should constitute area of interest in the field of organizational study or discourse of what happens in the work. In this wise, the development and the acquisition of skills at the required levels by all workers in the public service sector becomes a study target as it obtains in this paper. It should be noted, however, that the public service sector is growing in nature and scope by the day, in response to the immediate and external socio-political and economic developments, especially in the content and context of the globalization trends and Millenium Development Goals (MDGs). For this public sector to meet their increasing responsibilities, they require responsive and well equipped workers in terms of necessary knowledge, attitudes and adequate skills to enhance their on-the-job-behaviour for effective and efficient service delivery on the parts of their employing public sector units (Oladunni 1998). This, he opines, could be better realized if the Nigerian tertiary institution, particularly the universities and professional associations such as the Chartered Institute of Personnel Management of Nigeria (CIPMN), the Nigerian Institute of Management (NIM), Administrative Staff College of Nigeria (ASCON) and a host of others, focus more seriously on the training and development of Human Resource Practitioners who will in turn train and develop the Nigerian public sector employees of all categories. It will be in form of training-the -trainer model for human resource skills provision by making such trained trainers professionals in the area of skill development in the proper sense of it. This responsibility rests squarely on the organization based Human Resource Development managers and their outdoor professional counterparts (consultants).

\section{Human Resource Management and Workers Development Training}

The terms Human Resource Management (HRM) and human resources (HR), according to Amstrong (2006), have largely replaced the term 'personnel management' as a description of the process involved in managing people in organizations. Human resource management in this context, and leaning on the Amstrong frame of reference, is the strategic and coherent approach to the management of an organization or nation's most valued asset, which is the human elements who are individually and collectively contributing to the achievement of the objectives of such organization or the nation. Human resource management is a process containing a set of 
activities for staffing the work organization and for sustaining high employee performance (Robbins and Courtler, 1994). Human resource management is also seen by Bartol and Martin (1998) as the management of various activities designed to enhance the effectiveness, and efficiency of the workforce of corporate organization and or the entire workforce of a nation. Gomez-Mejia, Balkin and Cardy (1995) maintain that the most valued resource in all the sectors of an economy is managed by using human resources to help corporate bodies gain, or maintain competitive advantage now and in the future.

The panoramic descriptions so far on human resource management confirm joint emphasis and harmony of opinion and perception on the need to bring out the best out of the employees of corporate organization in particular and the economy in general with total commitment to effective and efficient employee job performance. Thus, Human resource management could be made possible through management process which is containing planning, staffing, development and evaluation, compensation and maintenance of the workforce as depicted in the figure 1.

The issue of human resource development takes a prime position and forms an important aspect of human resource planning. It is as topical as it receives attention of managers of organizations and the nation at large. The need for the education and training of the workforce points to the relevance and importance of the human element in the production of goods and services of all the productive sectors of an economy.

\section{The Relevance of Human Resource and the Need for Employee Development}

Human resource constitutes the people who make things happen in organization and are thus very relevant to the existence, growth, development and survival of their employing organizations. They constitute the nation's workforce and are therefore responsible for the production of goods and services. The need for their motivation through education and training for relevant skills acquisition for effective performance cannot be over emphasized. "Our people are our most important asset" has been a common assertion among managers of organizations. The above scenario is supported by Robbins and Coutler (1999) when they opine that human resource can be an important strategic tool which can contribute to the development of organization's sustainable competitive advantage. They also affirm that various studies have concluded that an organization's human resources-its people- can be a significant source of competitive advantage. It has also remained a necessity for managers to make decisions about employee training as an avenue for skill acquisition, and to provide career advice to subordinate workers. Many economies in the world over, including Nigeria have begun to recognize the important role that employees play in their economic success. Therefore, they have been committing themselves to strong human resources development (HRM) departments and other agencies responsible for developing effective workforce.

In Nigeria, there are designations, such as Directors and Departments, Developments and Boards such as civil service training schools, bureau of establishment and training, local government training school, among others, that are directly charged with the duties of training and development of workers. Most shortcomings of workers that occur in the provision of goods and services, especially wastages, damages, among others, are unnatural; rather they are caused by people due to either lack of or inadequate training. Only small percentage happens from system and natural sources. Such wastages and human errors could be significantly reduced if not prevented by better employee training (Robbins and Coutler, 1999). The point being made here is to illustrate the importance of employee training in the workplace.

\section{Human Resource Management and Employee Development}

Essentially, employee training and development are at the heart of employee utilization, productivity, commitment, motivation and growth. However, many employees have failed within their individual separate organizations because their training need have not been properly identified and provided for as indispensable part of management function. Such identification and provision as opined by Nwachukwu (1988) are facilitated by first isolating a distinction between training and development. Training relates to all efforts aimed at helping an employee to acquire basic skills required for efficient execution of the functions for which he or she has been hired. While development deals with the activities undertaken to expose employee to perform additional duties and assume positions of importance in organizational hierarchy in an economy. For the purpose of this work, training and development are used interchangeably since the distinction between the two terms is often blurred. Though, training denotes efforts to increase employee skills on present jobs and the term development refers to efforts oriented towards improvement relevant to future jobs. According to Bartol, and Martin (1998), upgrading skills in present jobs usually improves performance in future jobs. The organ responsible for this role is the human resource, a unique formation generally designated as department comprising human resource managers, specializing in various aspects of human resource management. Among these are human resources professionals. This is because of their training, practice and experience as those who deal specifically with issues of staff training and development organizations in Nigeria. Such specially trained professionals are found as development officials in government formations (Federal, State and Local Government) at Ministries, Training Institute and Centres, Parastatals, Educational Institutions, especially at the tertiary levels and other statutory agencies. Some of them operate as skills acquisition centres.

It is a fact that as jobs demand change, employee skills have to be altered and updated. This requires deliberate efforts on the part of the human resource development managers as a specialized segment of the corporate 
human resource management who are regarded as in-house or organization based employee development professionals.

The responsibilities of professionals, whether from within or consultants, in updating the skill level of all categories of workers are numerous. These include:

(a) Provision of human resource development framework in line with the main human resource management policy in response to the overall corporate development towards high performance to achieve required competitive advantage. In this respect, the concept and practice of competency-based, HRM is put into use, whereby competencies represent the language of performance. The emphasis on competency issue is central in this regard. This is because it is the underlying characteristic of an employee that results in effective or superior performance practice in their work (Rankin, 2002).

(b) Provision of Human Resource plan that integrates effective human resource development practice, in which the concept of human capital management approach is adequately employed. Such approach, according to Amstrong (2006), will generate questions to which HRM must provide answers through its in-house human resource development professionals.

- How are we going to attract, develop and retain these skills?

- How can we develop a culture and environment in which organizational and individual learning takes place and meets both our needs and the needs of our employees?

- How can we provide for both the explicit and tacit knowledge created in our organization to be captured, recorded and used effectively?

In this stead 'people' - the workers are in focus. Hence, the HRM's basic concern is people- who are in organization, their skills and competencies on hiring; what skills, competences they develop through training and experience; their level of qualification; and the extent to which they apply organizationspecific or generalized human capital.

(c) Facilitating a level ground policy that will encourage human resource development synergy between the organization-based human resource development professionals and the outsourced development professionals in the areas of funding, infrastructure and other management support for the training and education of employees. In addition, special attention is very necessary to be focused on the low-skilled segment of the workforce.

(d) Through adoption of the concept of a learning organization, the commitment of the organization towards the development of entire workforce and personal self development programmes, in terms of skills acquisition and other forms of employee development, becomes central themes of management commitment to high performance.

\section{The Synergy between In-House and Outdoor Human Resource Development Professionals}

The synergy between the two parties is premised on the concept of learning organization which is the encouragement of identification of individual training needs, organic formulation of business strategy with inputs from training departments on current skills, and continual organizational review and learning from experience. This organizational learning cycle is shown in the figures 2,3 and 4

\section{Low skilled worker}

The concept of low skilled worker seems to enjoy wider space in organizational study literature than the concept of un-skilled workers. However, the concept of low-skilled workers should be preferred in the sense that hardly can a worker be in an organization without any skill. What is obtainable borders on skill level relativity which should be emphasized for programme of actions. In this context, the phrase "low skilled workers" should be conceived as employees whose skill level fall short of the degree required for the efficient and effective performance of their job-holding; that is, those whose skills fall short of adequate cognate skills of their job performance.

The types of human resources development which the partnering of the joint development professionals should aim at:

- System development capacity;

- Organizational allocation of training responsibility;

- Decision making on training needs identification and training needs assessment; and

- Forecasting and predictions.

Essentially, the primary activities involved in employee resource development are orientation, training in job skills and cultivation of management skills. Evaluating performance, counseling and mentoring are the other parts of the responsibilities of both the internal human resource developers and the external human resource development professionals in the various organizations of an economy.

The end product of these principles when employed by the two parties should result in strength, weakness, opportunities and threat (SWOT) programmes to know the areas to be tackled in favour of low-skilled workers' strength, weakness, opportunities and threat. This will facilitate the availability of skills through skill development training such as technical skills, administrative and interpersonal skills. Multi-skilling and scheming should be part of the training programmes to be embarked on through the joint commitment. This will 
help flexibility and mobility of workers who are experiencing low-skill level regarding their job performance. Variety of training to enhance multi-skilling becomes imperative in arresting low-level skills of employee in the organization because of its numerous advantages, as has been pointed out

\section{Recommendations}

(i) Efforts should be made to employ appropriate training philosophy and programmes that would attract good attentions coupled with appropriate skill, induced method and processes by the social partners. These will include job analysis, training specification, job evaluation, skill-gap and analysis.

(ii) Adequate updating of skills requires the joint efforts of the organization based HR managers and their external HR developers (consultants) in terms of policy formulation and implementation towards employee skills acquisition and utilization within a nation. Both are enjoined to work together in order to achieve the objectives of monitoring training programmes for low-skill employees.

(iii) Enough funds should be made available for the training of low skilled workers in organizations in order to benefit the nation.

(iv) The use of internal and external human resources managers is dependent on the availability of funds to organizations. However, the development of the organizations and the inherent benefits in training employees should be paramount in the minds of managers in various establishments.

(v) When external HR professionals are invited to an organization, certain challenges such as finding, appreciating the philosophy of the establishment, and attitude of resource persons come to the fore. Therefore, external HR professionals are enjoined to understand the philosophy, objectives and aspirations of their client before embarking on any HRM with such an organization.

\section{Conclusion}

The contribution of this paper to knowledge is that, hitherto the concept of unskilled worker is emphasized. Whereas at whatever level's of one's working experience, one may be low-skilled given certain factors such as adoption of new technology for production, environmental factors, and government policy, among others. For instance, Cedefop (2002) and Hassan (2009) opine that perception on training for employees have changed because of two important factors: investment in information and communication technologies (ICTs) and globalization. That is why skills provision for employee at whatever level requires a lot of efforts, commitment and sincerity on the part of all providers on the one hand, and the employees on the other hand owing to the relevance of skills in either business, organization or a nation's economy. The accomplishment of adequate and appropriate skills is always faced with some challenges. These challenges include funding, human and materials resources, management insecurity, providers' attitude, employees' attitude as well as other environmental factors.

\section{References}

Adegbola, W. (2000). 'Strategic Management in the Nigerian Banking Industry.' Paper Presented at the Practical Orientation Programme for MBA Students in the University of Lagos, Nigeria.

Argyris, C. (1992). On Organizational Learning. Backwell, Cambridge, M.A.

Armstrong, M. (2006). A Handbook of Human Resource Management Practice. Philadelphia, U.S.A.: Kogan Page Ltd.

Bartol, K.M., and Martins, D.C. (1998). Management. New York: MCGraw-Hill.

European Centre for the Development of Vocational Training (Cedefop). (2002). Competence and Human Resource Development in Multinational Companies in three European Union Member States, Luxenbourg:

Gomez, L. R., Balkin, D.B., and Cardy, R.L. (1995). Managing Human Resources. New Jersey, U.S.A.: Prentice-Hall Inc.

Hassan, M A. (2009). Empowering Trainers of Adult Educational Personnel in Nigeria. International Journal of Education, Issues, 4, (1) January - June

Ifechukwu, B.M. (1989). The Management of Parastatals in : Alex, G and Yaya, A (eds) (1989) Nigeria Since Independence: The first 25 Years. Public Administration: Ibadan: Heinemann Books.

MAMSER. (1987). Report on the Political Bureau. Abuja, Nigeria: The Directorate for Social Mobilization.

Nwachukwu, C.C. (1988). Management Theory and Practice. Ibadan: Africana Publishers Ltd.

Obisi, C (2003). Human Resource Development and Reservation. Human Resource Management: Journal of the Institute of Personnel Management of Nigeria, Vol III, No. 1.

Oladunni, S.A. (1998). Issues in Corporate and Human Resource Management in the Oil Industry. A Collection of Essays, Lagos: Tom Micro Publishers Ltd.

Otobo, D and Omole, M. (1987). Readings in Industrial Relations in Nigeria. Lagos: Malthouse Publishing .

Pickard, J. (1997). A Yearning for Learning. People Management, Vol 3. No. 5.

Rankin, N. (2002). Raising Performance through People: The Competency Survey, Competency and Emotional Intelligence. January Edition.

Robbins, S.P., and Courtler, M. (1999). Management. New Jersey: Prentice Hall Inc. 


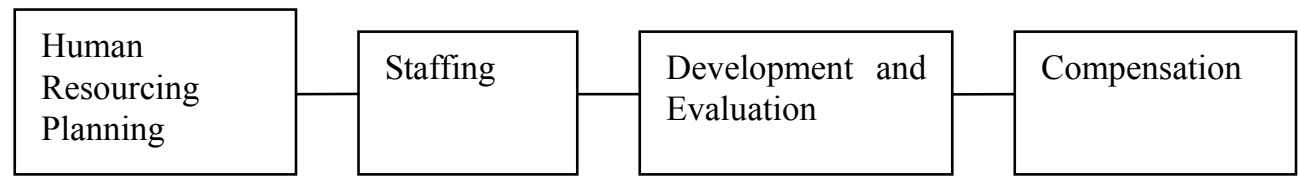

Figure 1. Human Resources Management Process

Source: Adopted from Bartol, K.M. and Martin, D (1998) Management. New York.

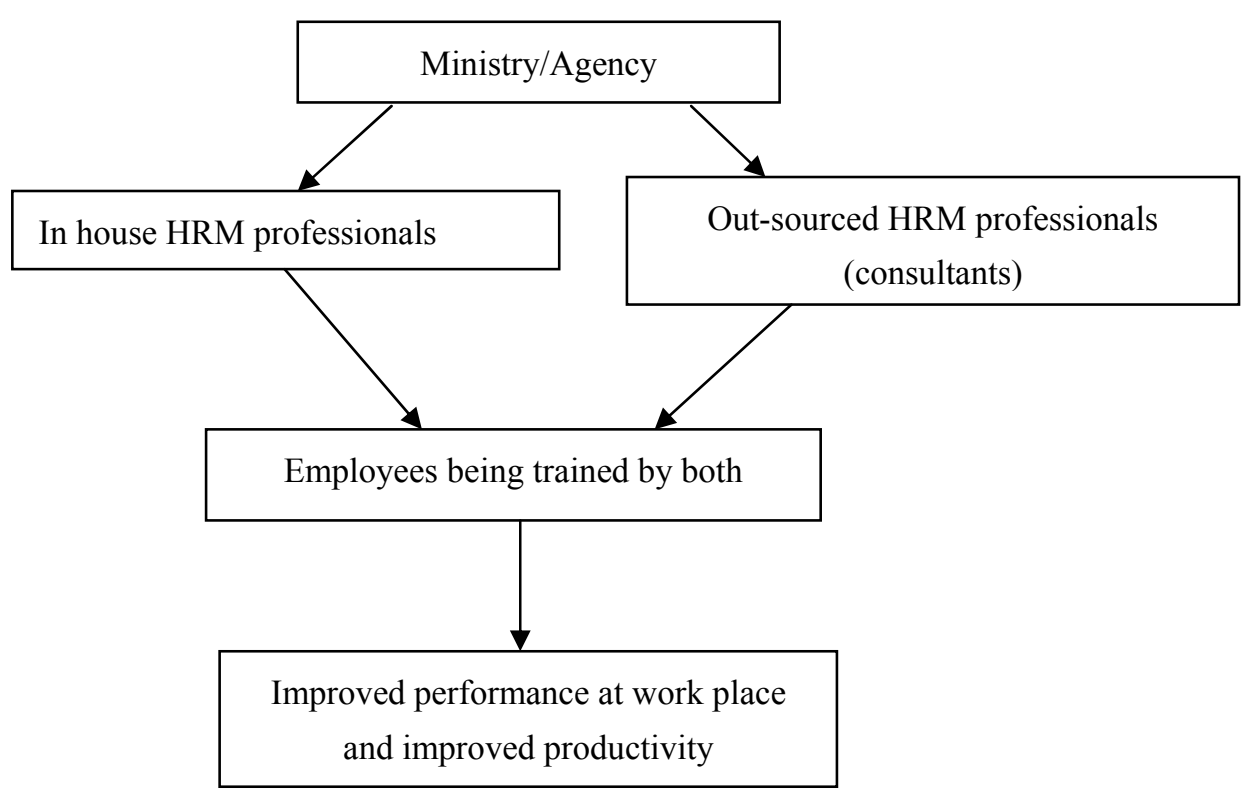

Figure 2. Relationship between inside and outside HRM professionals

Source: Developed by Aroge S.T and Hassan M.A (2011). The Responsibility of Human Resource Management and Development Professionals in the Development of Low-Skilled Workers in the Nigeria Public Sector 


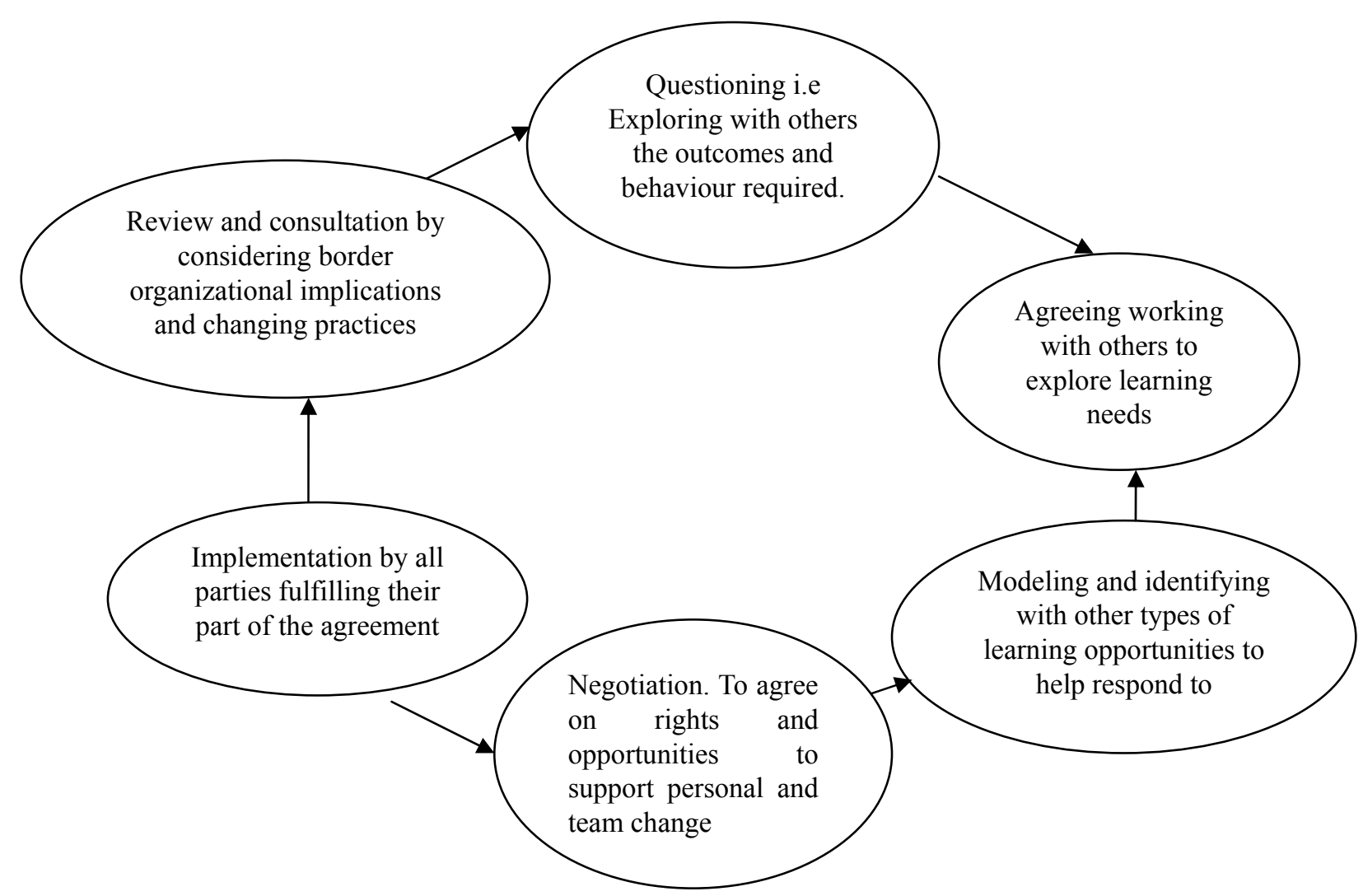

Figure 3. Organizational Learning Cycle

Source: Pickard, J. (1997). A Yearning for Learning: People Management, 3 (5)

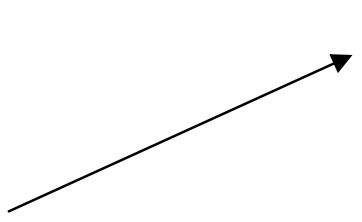

Double Expectation
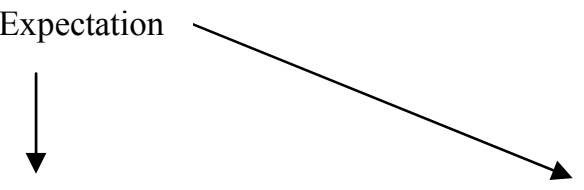

Take action

Decide on corrective Monitor and review action as necessary

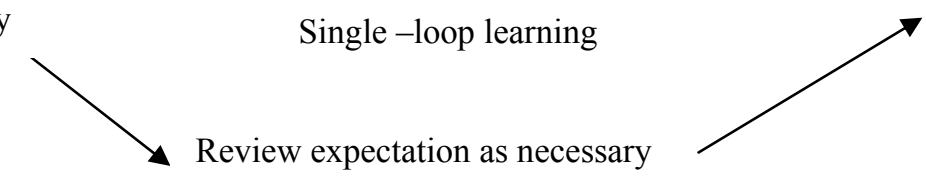

Figure 4. Organizational Learning

Source: Argyris, C. (1992) On Organizational Learning, Backwell, Cambridge, M.A. 